\title{
Challenges of typyfing nominal infinitive sentences in modern Russian
}

\author{
Natalia Gerasimenko ${ }^{1, *}$ \\ ${ }^{1}$ Moscow Region State University, 10 A, Radio Str., 105005, Moscow, Russia
}

\begin{abstract}
The present paper investigates nominal infinitive sentences in terms of their grammatical parsing. For this purpose, a structural-semantic method was applied. When performing structural analysis of a sentence, students often experience certain difficulties trying to distinguish its subject and predicate. The purpose of this work is to manage the challenges of defining subject and predicate in a sentence when learning Russian in school or university. Specifics of using an infinitive as a subject is substantiated; semantic groups of nouns that get in connection with infinitives are described. It was defined that in nominal infinitive sentences, the infinitive acts as a subject, while the noun performs a function of the main component of a copulative-nominative predicate. In most cases, an adjective relating to a noun that acts as a predicate is considered a part of that predicate. Nominal infinitive sentences have a limited group of special copulas functioning.
\end{abstract}

\section{Introduction}

In the Russian language, there is a group of sentences that are quite challenging in terms of performing their structural analysis. This refers to sentences of the following type: Дарить было её любимым занятием (To give was her favorite act) (Tatyana Tolstaya); Отделаться так дёшево - редкая удача (To get off so cheap is a great piece of luck) (Max Frei). [In order to convey the grammar structure of source sentences used as examples, the word-for-word translation from Russian into English is applied]. We refer them to two-member sentences and call them nominal infinitive ones [1]. The traditional form to express a subject in the Russian language is the nominative case of the noun, but in nominal infinitive sentences it usually acts as the nominal part of a predicate, while the infinitive verb plays the role of a subject. Divergences in designating principal parts of the sentence are observed in classical works on syntax and in contemporary works as well. For instance, A.A. Shakhmatov attributed such sentences to the type of two-member inconsistent sentences. He noted the possibility of their reversibility, which means that the change in the order of principal parts of such a sentence causes the change in their functions. The fundamental inconsistency of principal parts in such a sentence consists in the absence of matching grammatical categories in the noun and the infinitive. Even the category of grammatical number possessed by verbs and nouns does not manifest itself in a verb infinitive. An infinitive that is placed before a noun is presented as the first member,

\footnotetext{
* Corresponding author: doptaganka@yandex.ru
} 
while the infinitive in the postposition to the noun - as the second member [2]. The terms "first member" and "second member" according to A.A. Shakhmatov nominally correlate with the modern understanding of a subject and predicate and reflect the position principal parts of a sentence. P.A. Lekant in his works expressed the similar opinion: "The infinitive belonging to a compound nominal predicate has an attitudinal meaning due to the correlation with a subject that has abstract semantics: 'assignment' (goal, task, purpose, etc.) or 'activity' (action, work, etc.)" [3].

The academic "Russian Grammar" presents the following consideration of nominal infinitive sentences: "Subject-predicative sentences are constructed according to those patterns in which a semantic subject is expressed through the nominative case of a noun or through the infinitive; the first component is a noun in the nominative case or an infinitive that means a semantic subject; the second component is a form that embodies the meaning of a predicative attribute; it is called a predicate" [4]. The function of a subject peculiar to both the nominative case and the infinitive is theoretically indicated, however, the examples show two structural-semantic schemes: $\mathrm{N}_{1}$ - Inf (Задача - учиться (The task -(is) to study)) and Inf - $\mathrm{N}_{1}$ (Трудиться - доблесть (Tо work -(is) valor)), which allows seeing the fairness of Shakhmatov's theory on the reversibility of nominal infinitive sentences. The refinement of this tradition can be found in the dictionary and reference book "Grammatical terminology" of V.N. Nemchenko. The author considers nominal infinitive sentences controversially. On the one hand, this type of sentences is described in the dictionary article "Reversible Two-member Sentence": "A two-member sentence, where switching the positions of the principal parts is allowed" [5]. Grammatically heterogeneous sentences are given as examples: The father-(is) a worker; My dream-(is) to learn. On the other hand, a nominal infinitive sentence is represented one of the examples in the article "Nominal Sentence (of infinitive-nominal order): "A nominal sentence, where a predicate is expressed through a noun and a copula in the form of an infinitive, for example: Eмy быmb учителем (Hе (is) to be a teacher); Его цель - сделаться героем романа (His goal (is) to become the hero of a novel)" [5]. In the latter case, there is no distinction between a onemember infinitive sentence and an inversed nominal infinitive sentence. B.N. Golovin explained the typology of the Russian subject in accordance with the method of morphological expression as a contrast of substantive, substantiated, non-substantive and substitute forms of a subject [6]. This typology designated an infinitive subject to nonsubstantive forms; the issue of the compatibility of the infinitive with a noun in a predicative use was not considered. However, listing the ways to express a predicate, Golovin does not name the infinitive form [6]. The presented brief overview of opinions on nominal infinitive sentences suggests the need to study these sentences and determine their place in the system of Russian two-member sentences.

\section{Materials and methods}

The current Russian language experiences the increased use of syntactic constructions of an analytical nature [7,8], including nominal infinitive sentences (analyticity of these sentences is manifested in the fact that predicative meanings are expressed through a copula): И чем меньше и беззащитней населяюшие дом существа, тем большим чудом покажется жнть с ними под одной крышей, пить единую воду, вдыхать воздух, в который с таким старанием вплетают свои струйки резные носы кота и щенка (And the less and more vulnerable the creatures inhabiting the house are, the greater miracle would it seem to live with them under the same roof, drink the same water, inhale the air into which the carved noses of a cat and puppy are weaving their treads with such diligence) (M. Tarkovsky). This is explained by many factors, but first of all, as we think, by intellectualization of modern language [9]. The use of analytical constructions in 
speech reflects the mental operations performed by the speaker. These can be operations of identification, interpretation, characterization, comparison, assessment, etc. The speech of a modern man reflects the increasing attention of society to the personality, manifestations of both intellectual and emotional, mental personality traits. Hence there is the increased role of characterizing and attitudinal statements in modern fiction, the language of mass media and colloquial speech. Nominal infinitive sentences, as well as in bi-substantive, substantive-adjectival and similar analytical types of two-member sentences give a modal characteristic: an assessment of an independent attribute (process), named by a subject: Гладить костюмы - моя обязанность (Tо iron costumes -(is) my responsibility) (Е. Chizhova); Кощунство было даже думать об этом (Blasphemy was even to think about it). (L. Ulitskaya). The difficulty in distinguishing between the functions of a subject and a predicate in a nominal infinitive sentence has led to the need of the research into these type of sentences. Approximately 350 examples of nominal infinitive sentences that comprised the study's card index were selected by continuous sampling from the works of contemporary authors (fiction books of the XX-XXI centuries), mass media (mainly Komsomolskaya Pravda newspaper, certain glossy magazines): $A$ вот реализовать мечту - это настоямее искусство! (To realize the dream is real art!) (Komsomolskaya Pravda); Вообще верить, что музыка приносит пользу обществу, - заблуждение (In fact, to believe that music benefits society is a delusion) (A. Chervinsky). These examples clearly express the speaker's point, which consists in assessing the possible process "to realize" as art and process "to believe" as a delusion.

The multidimensional nature of a Russian sentence obstructs the determination of a subject's and a predicate's functions in many cases, since the semantics of morphological forms conflicts with communicative (actual) parsing of a sentence, and grammar conflicts with logical parsing [10], etc. The aforesaid indicates the need for a deeper study of the functions of the principle parts of nominal infinitive sentences. Adequate analysis of the principle parts of such sentences helps rightly understand the meaning of a phrase, which is the most important part of teaching the Russian language. The modern structural and semantic method of linguistic research, which encompassed the achievements of semantic, cognitive and communicative syntax, yet prioritizing structural and semantic analysis, is the most relevant to the purpose of this work.

\section{Discussion}

When analyzing nominal infinitive sentences, mistakes in interpretation are made not only by students, but also teachers, developers of tasks for exams and academic competitions. For instance, one of the tasks of the Moscow Academic Competition said to form a sentence according to the scheme: a consistent or inconsistent attribute + subject nominative case of a noun + predicate - infinitive [11]. They meant a sentence of the following form: Наша задача - учиться (Our task is to study). Therefore, the infinitive was considered as a predicate in the task.

1. As it is known, the infinitive is a grammatical form that is not able to convey predicative meanings required for a predicate: modality, time, syntactic person. Therefore, the infinitive cannot fulfill the predicate function by its own. For the fulfillment of this function, a copula is required for the infinitive as well as for any other morphological form that does not have grammatical categories of modality, time and syntactic person, which altogether form predicativity as the grammatical meaning of a sentence. The combination of an infinitive with a copula may be observed in bi-infinitive sentences, in which both a subject and predicate are communicated through infinitives: Но ульбнуться - значило спугнуть и смутить девушку (No, to smile meant to frighten and embarrass the girl.) (A. Green); В конце концов мыслить предмет - это значит устанавливать 
систему отношений, царящую как в нём самом, так и в его связях с другими предметами (Finally, to think of an object means to discover a system of relations that lives both in itself and in its relations with other objects) (A. Losev). A bi-infinitive sentence with a copula verb possesses a complete modal-and-time paradigm [12] unlike nominal infinitive sentences (see: paragraph 4).

2. In nominal infinitive sentences, a copula is not compatible with the infinitive, but with the noun, forming a semantic-grammatical unity that acts as a predicate: Действительно, вода показалась ледяной, но какое блаженство было шлёпать босыми разгорячёнными ногами по этой воде (Indeed, the water seemed icy, but what bliss it was to slop with shoeless heated feet on this water) (V. Soloukhin). The infinitive илепать (to slop) receives an assessment какое блаженство (what bliss) and predicative characteristics of the real objective modality, the past tense and the third syntactic person, as it indicates a potential action in relation to the speaker, who is not a participant of the situation. (What is it said? - to slop; how is this process assessed? - было блаженство (bliss it was); the alternative было блаженством is also possible). The copula было (was) is singular and of neuter gender, which is not just because it is consistent with the noun блаженство (bliss) which is also of neuter gender. This form of copula expresses conventional coherence as a grammatical relationship between the predicate and the subject. "Conventional coherence refers to a subject expressed by uninflected words or those words that do not have forms of number and gender. The convention of coherence consists in the fact that a predicate's number (gender) is not motivated by adaptation to the similar form of a subject, but determined by the absence of these forms in the subject" [13].

3. In many cases, a copula in nominal infinitive sentences is consistent with a nominal part of the copulative-substantive predicate, the main part of which expressed by a noun has categories of number and gender: Превратить сонное чарство, готовое уже претерпеть новый грандиозный распад, как при нашествии монголов, в современное европейское государство - такова была всепоглощающая и маниакальная цель (То turn the land of Nod, which was ready to undergo a new grand decay, just like during the Mongol invasion, into the modern European state - that was the encompassing and maniacal goal) (A. Aksyonov); Сидеть в кабинете и отдавать приказы - это был для меня новый, совершенно фантастический опыт (To sit in the office and give orders was $\boldsymbol{a}$ new and absolutely fantastic experience for me) (Max Frei). In these cases, the coherence of the copula with the nominal part emphasizes the grammatical unity of the predicate. "Copulas cannot verbalize a name morphologically, they only facilitate the transit of non-verbal words into the functional class of predicates, compensate for the missing categories necessary for expressing the predicative meaning of nominal parts of speech" [14].

4. The grammatical feature of nominal infinitive sentences in Russian is the prevailing use of the zero form of copula " $t o$ be", which is conditioned by the standard semantics of such sentences, in which the characteristic or assessment of a potential action is expressed via infinitive: Смысл моей жизни - уберечь нашу бедную планету от оккупации (Тhe meaning of my life -(is) to protect our poor planet from occupation) (B. Akunin); Попрошайничать - удел медведей, обезьян и людей (Tо cadge -(is) the destiny of bears, apes and people) (S. Lukyanenko). Such a usage conveys the meaning of timelessness, which is peculiar to sentences of attitudinal and characterizing type. In some individual cases, in accordance with the style of presentation, a materially expressed form of the present tense can be used - to be - is. This is customary for, for example, V. Nabokov's individual style: Обнаружить и проследить на протяжении своей жизни развитие таких тематических узоров и есть, думается мне, главная задача мемуариста (To discover and trace the development of such thematic patterns throughout their life is, I believe, the main task of a memoirist) (V. Nabokov). In this case, the 
semantics of timelessness is preserved. The use of the copula ecmb (is) together with the conjunctive particle $u$ (and) [this feature is not preserved in the translation] emphasizes the speaker's confidence in faithfulness of his assertion. The copula ecmb (is) is used mainly in scientific and journalistic writings and has a bookish vibe in modern Russian.

Less often, yet usually quite effectively, the semantics of the past tense is realized in nominal infinitive sentences, which is expressed mainly through the copula бotmb (to be): To speak, to convince, to resist - anyways - was useless (A. Tolstoy). The copula бblmb (to be) in the future tense is theoretically possible, yet such a use implies a previous or subsequent context associated with a certain event, confer: To buy a villa in Spain-(is) not a problem for me (S. Andreev) - *To buy a villa in Spain will be no problem for me (if something happens). Perhaps the future tense does not correlate with the standard attitudinal and characterizing semantics of nominal infinitive sentences. In our card index, there are no forms of the future tense contained in the nominal infinitive sentences. This also refers to the use of the copula бamb (to be) in irrealis moods. In some particular cases and for some special purposes, the form of the subjunctive mood of the copula can be used: Но не думаю, что было бы в интересах следствия сейчас распространяться об этом (But I don't think that it would be helpful for the investigation to spiel about this now) (M. Shishkin). In the above example, this form is a part of the idiom. There are no forms of imperative in our card index. Just as in case with the grammatical sense of time, the moods (except indicative) destroy the aphoristic character of nominal infinitive sentences, therefore they are rarely used.

Components that complicate a copulative-substantive predicate add new connotations to a statement. The predicative attribute assigned to a subject usually acquires an additional modal connotation of obligation, opportunity, necessity, etc., which is superimposed on the copulative semantics of subjective perception: Это ли значит, что «юность витает в облаках»: быть похороненным и оплаканным на чужой земле могло показаться мне счастьем! Does this mean that "youth is in the clouds": to be buried and mourned in a foreign land might seem happiness to me! (A. Bitov) - there is a complication of the form of a copulative-substantive predicate with a modal component having the meaning of possibility: might. Being complicated with additional modal connotations, the copula takes the form of an infinitive, which does not interact with the form of a complicating component. It is noteworthy that phase and emotional complicating components are not used with the infinitive subject.

5. Selective compatibility of the infinitive subject with copulas is noted. This is a limited group of specialized copulas expressing the general meaning of attributing a predicative quality (characteristic, assessment) to the subject. To express such a typical meaning in the Russian language, the "ideal" (in the definition of A.M. Peshkovsky) copula быть (to be) in the materially expressed or (more often) zero form: Другой метод сократить время общения с таким горе-боссом (Another method is to reduce the time of communication with such a miserable excuse for boss) (Komsomolskaya Pravda). Along with this copula, in the nominal infinitive sentence, copulas with the same typical attribution of a quality, but having their own additional connotation may be used: Добираться с Крестовского на Шиалерную стало делом долгим (То get from Krestovsky to Shpalernaya has become a long affair) (D. Bykov); Разговаривать с ней [женой] сделалось для него настоящей пыткой (To talk with her [wife] became a real torture for him) (T. Polyakova). Copulas cтать, сделаться (become) bring the meaning of change, of establishment of an attribute into a sentence. The copula оказаться (to appear/turn out to be) is also used in nominal infinitive sentences; it introduces a hint of 'inconsistency with expectations': Дозвониться до Зойки Лазаревой оказалось не таким простым делом (To reach Zoyka Lazareva by phone turned out to be not so simple) (D. Dontsova). Copulas with the meaning of perception subjectivity (показаться, 
представляться (sеem), etc.) emphasize the personal perception of the quality being attributed: Обесточивать что бы то ни было в лабораториях Федора Симеоновича представлялось мне просто кощунством (To de-energize anything in the laboratories of Fedor Simeonovich seemed just blasphemy to me) (Arkady and Boris Strugatsky). There is often a dative subject in such sentences - a pronoun or a noun in the dative case, that indicates a person who gives the assessment: Заниматься спортом часто кажется ребёнку очень трудным занятием, но ваме участие поможет ему справиться (То gо in for sports often seems a very difficult task for a child, but your engagement will help them cope) (Karavan istoriy). A combination of a noun or pronoun in the genitive case and the preposition для (for) fulfills the same function in this type of sentences: Для журналиста написать заметку пустяк (То write an article for a journalist is a trifle) (Komsomolskaya Pravda). The absence of the named components in the text indicates the speaker as the one who makes an assessment or characterization.

The statistics on the use of copulas with infinitive subjects are shown in chart 1.

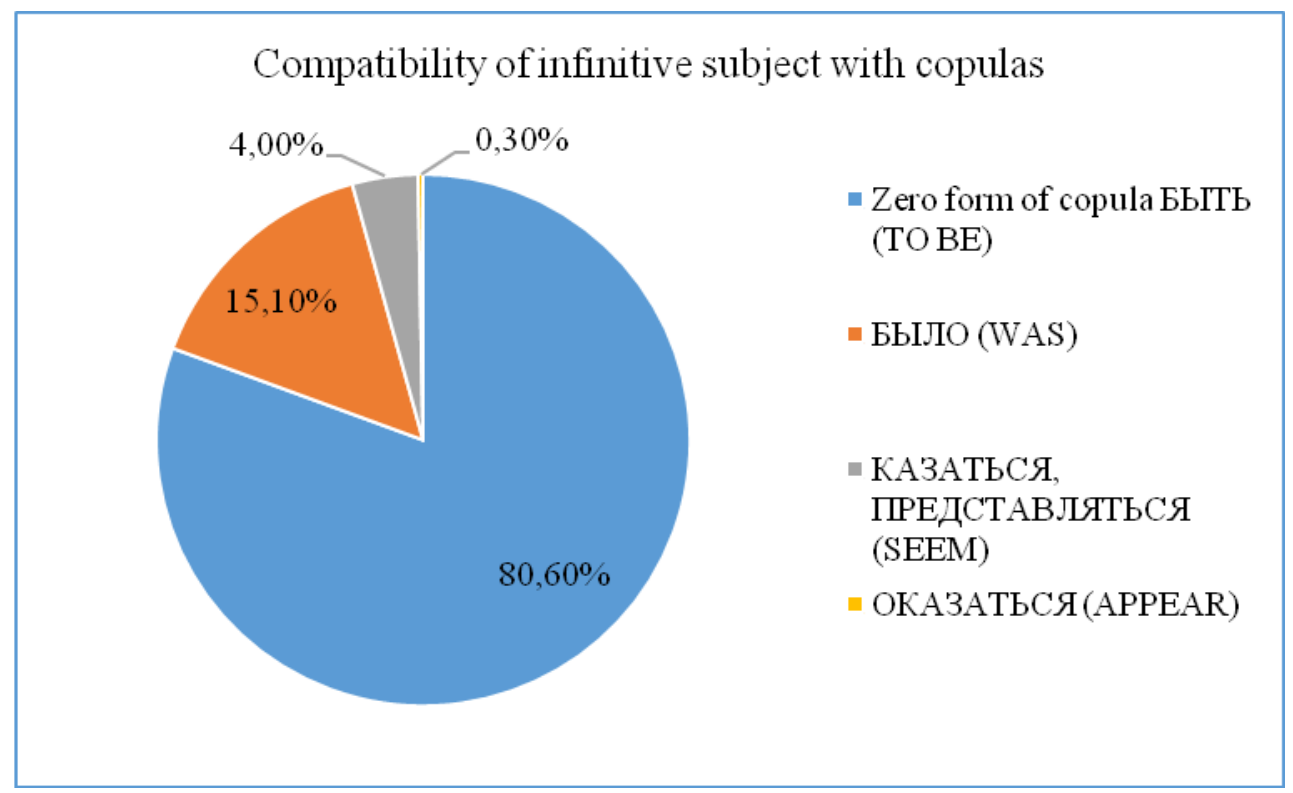

Fig. 1. Compatibility of infinitive subject with copulas.

6. In terms of semantics, most nominal infinitive sentences have a standard meaning of attitude. Evaluation is expressed in a copulative-substantive predicate via vocabulary of attitudinal meaning; axiological adjectives that make up a predicate; sometimes via a metaphor. Attitudinal nouns make up the vast majority of the predicate in nominal infinitive sentences. Depending on the componential structure of the attitudinal word, the expressed assessment may be either positive or negative. A positive assessment usually combines feelings and a state corresponding to the attitude expressed: Заполучить в родственниць такую красотку просто счастье (To get such a beauty as a relative is pure happiness) (T. Polyakova); Пожалуй, главное наслаждение бытия - внимать речам ученого мудреца, о чём бы тот ни вещал (Perhaps the main pleasure of being is to listen to the speeches of the learned sage, no matter what he talks about) (Е. Chizhova); Omdeлаться так дёшево - редкая удача (To get off so cheap is a great piece of luck) (Max Frei). Attitudinal semes are part of the lexical meaning: happiness is 'a feeling and state of complete, higher satisfaction' (Ozhegov: 696); pleasure is 'the highest level of pleasure' (Ozhegov: 345); luck is 'desired success or desired outcome' (Ozhegov: 734). Он был 
прав: уступить достойному противнику - это не позор (Hе was right: to concede to a worthy adversary is not a dishonor) (Arkady and Boris Strugatsky); dishonor is 'shame, humiliating position that evokes contempt' (Ozhegov: 485). The lexical composition of the sentence (достойный противник (worthy adversary)) and the presence of a particle не (not) before a noun позор (dishonor) turn a negative assessment into positive.

A negative assessment refers to potential actions entailing negative consequences: Невероятное нахальство - делать замечания отиу (It is the incredible impertinence to admonish your father). (Y. Trifonov); нахальство (impertinence) is 'an impudent act, arrogance' (Ozhegov: 349). Жить без любви - несиастье (To live without love is a misfortune) (V. Tokareva). According to the explanatory dictionary, несчастье (misfortune) is 'a woeful event' (Ozhegov: 363). In this sentence, the noun misfortune is used as the opposite of the word happiness, in a negative meaning of 'the lack of feeling and a state of complete, higher satisfaction', since this does not refer to a particular woeful event, but to life in general. A negative assessment is often expressed metaphorically: Подниматься и спускаться по лестниче - ежедневное испытание, дорога до ближайшего магазина - полоса препятствий (То gо ир and down the stairs is a daily test, the road to the nearest store is an obstacle course) (Komsomolskaya Pravda). In nominal infinitive sentences, positive or negative assessments can be expressed with the help of phraseological substantive word forms: Мне двор убрать - в радость, как Льву Толстому сено покосить (It's a joy for me to clean the yard, like mowing hay for Leo Tolstoy) (S. Lukyanenko); Учиться им в тягость, вот они и гуляют (Tо learn is a burden for them, so they skip school) (Komsomolskaya Pravda).

Attitudinal meaning can be introduced into the predicate via an adjective, which, in combination with a neutral noun, forms an axiological statement: Но разгадывать загадки было любимейшим занятием и в некотором роде даже источником заработка для Николая Александровича (However, to solve riddles was Nikolai Alexandrovich's favorite pastime and, in a way, even a source of his income) (B. Akunin). The neutral word pastime, combined with the superlative form of the adjective favorite acquires the attitudinal meaning. Подвижное, изменчивое лицо - одно из тех, что почти невозможно запомнить, даже опознать по фотографии - тяжкий труд (А moving, changeable face - one of those that are almost impossible to remember and even to recognize from a photograph is hard work) (Max Frei). Being neutral in axiological terms, the noun work acquires the attitudinal meaning being combined with the adjective hard. Adjectives having attitudinal or characterizing meaning are a part of a predicate.

7. The infinitive subject in nominal infinitive sentences can receive a modalcharacterizing meaning if the nouns of certain semantic groups enter into predicative relations with it. The limited compatibility is associated not with the grammatical features of the infinitive, but with its syntactic function of a subject in a sentence. According to P.A. Lekant, "an infinitive in a predicate acquires the attitudinal and characterizing meaning due to its coherence with the subject, represented by certain categories of nouns. The infinitive is used in a predicate along with the subject noun with a modal-attitudinal meaning (goal, task, purpose, happiness, pleasure, etc.) or with a general meaning of activity (business, pastime, work, etc." [8]. In our opinion, the infinitive has its own meaning. It refers to a potential process that does not occur in time (action, state, attitude), which can be characterized or assessed, but the process itself cannot become a characteristic of an object or other process. In bi-infinitive sentences, where both the subject and the predicate are expressed through an infinitive with a copula, [15] two potential actions are identified: Вирочем, не буду болтать, понять и значит простить... However, I will not talk, to understand means to forgive... (Y. Trifonov).

8. Nouns цель (aim), задача (task), назначение (purpose), which have the modal meaning of purpose as well as nouns счастье (happiness), наслаждение (enjoyment), 
padocms (joy), etc., which have an attitudinal meaning, are intended to fulfill the function of a predicate according to their functional semantics, since it is in the predicate that implements the modal and attitudinal meanings. It is known that a noun is a bi-functional sign that is able to function as a naming and predicate one [16].

The group of nouns used as parts of copulative-substantive predicates together with the infinitive subject includes nouns which mean aspiration (стремление (aspiration), мечта (dream), желание (desire), etc.): Восстановить на земле этот верный образ божественной Троиџы - вот в чём русская идея (To restore this faithful image of the divine Trinity on earth - that is the Russian idea). (M. Shishkin). In nouns of a common meaning, the modal assessment of the potential action comes from a speaker. In nouns with the meaning of aspiration, the modal qualification comes from the one who can perform this action, cf.: Быть безгрешным - мечта дураков! (То be sinless is the dream of fools!) (S. Lukyanenko) and Когда-то ты впаривал мне, что основное предназначение человека - путешествовать, желательно - между Мирами, - ульббается Макс ("Once you tried to persuade me that the main purpose of a person is to travel, preferably around the Worlds" - Max smiles) (Max Frie).

Most of the nouns that perform a predicate function in nominal infinitive sentences are of abstract nature. Groups of abstract nouns are diverse; a whole research works work be devoted to their detailed description. The present paper pinpoints those that are often used in modern Russian. The semantic group that means 'a law, rule', is used mainly in journalistic speech: Работать творчески - закон для бригады (To work creatively is the law for the brigade) (Komsomolskaya Pravda). Phrases having the same meaning are also presented in fiction: Первое правило, - сказала баронесса, подавая Маше шёлковые чулки, - это держать ноги в порядке (“The first rule", said the baroness, giving Masha silk stockings, "is to keep your legs in order") (A. Tolstoy). A group having the meaning 'a way, method' is also commonly used in Russian: Поэтому мой любимый метод хвалить новичка за всякую малость, не забывая регулярно ужасать (That's why my favorite method is to praise a beginner for every little thing, not forgetting to regularly horrify him) (Max Frei); Лучший выход для меня - уехать отсюда побыстрее (The best way for me is to leave here as soon as possible) (T. Polyakova). Nouns coвem (advice), приказ (order), воля (will), etc. introduce the semantics of expression of will, causation of potential action into the principle parts of a sentence: Мой совет вам-отдаться в руки правосудия (My advice to you is to surrender to the hands of justice) (M. Slonimsky). Many abstract nouns enter into predicative relationships with the infinitive subject, forming special characterizing meanings. The main semantic restriction for such nouns is the abstractness of meaning: Что за странная фантазия - загнать махину в яму? What a strange fantasy is to drive a car into a pit! (T. Polyakova). General purpose nouns are not used as a copulative-substantive predicate.

8. When characterizing the infinitive as the main part of the predicate, most researchers proceed from the order of the principal parts of the sentence. This argument cannot be deemed sufficient. It should be noted that in nominal infinitive sentences, the actual parsing does not coincide with the grammatical one. Actual parsing allows highlighting the main component of the statement for a speaker, while grammatical parsing shows what kind of connections and relations develop between the sentence parts according to the rules of the Russian language. The reversibility problem [see Introduction] designated by A.A. Shakhmatov, is not a grammatical problem, it is the implementation of the communicative aspect of pronouncing. A formal change in the word order of a nominal infinitive sentence leads to the activation of the author's intention and emphasizes the meaning that is important for a speaker. The grammatical parsing of sentences takes into account not only the form, but also the ratio of logical volumes of concepts, the presence of characterizing, modal and attitudinal meanings in principle parts of a sentence. One may agree with the 
statement of B.Y. Norman, that "any speech product focuses on one of those syntactic models (structural schemes) that are embedded in the linguistic memory of a native speaker" [17]. Nominal infinitive sentences are one of such models with their special meaning and form.

\section{Results and conclusions}

The above description of the structure and semantics of nominal infinitive sentences, the functioning of the copulas in them, the manifestation of predicative meanings show that the infinitive takes the position of a subject regardless of the order of principle parts of a sentence. The following features prove this point:

- the infinitive as an unchanging grammatical form cannot convey predicative meanings of a predicate;

- a copula in a nominal infinitive sentence is consistent with the nominal part of a predicate expressed by a noun, since the infinitive does not have categories of gender and number; the coherence of a copula with a noun indicates the grammatical and semantic unity of a predicate;

- nominal infinitive sentences have features of the formation of predicative meanings: they primarily express the value of timelessness, which is grammatically conveyed through the zero form of the copula бolmb (to be);

- the past tense is freely implemented in a copula, since a potential action may be assessed in the past;

- the future tense is not typical for nominal infinitive sentences;

- forms of irrealis moods are not typical for this type of sentence;

- grammatical complication of the copulative-substantive predicate takes place due to the inclusion of components with a modal meaning; emotional and phase connotations are not peculiar to sentences with an infinitive subject;

- an infinitive subject is coherent with a limited group of specialized copulas: бblmb (to be), стать (to bесоте), сделаться (to bесоте); казаться (to sеeт), оказаться (tо арреаr), представляться (to seem), and some others expressing the meaning of existence, change and perception;

- the semantics of nominal infinitive sentences is manifested in the attitudinal and modal-attitudinal basic meanings;

- attitudinal meaning is expressed by attitudinal nouns and adjectives, which are included into the predicate; phraseological units and idioms;

- modal-attitudinal meaning is determined by numerous groups of nouns that comprised abstract nouns (purpose, business, aspiration, law, etc.).

The described features of nominal infinitive sentences show that the infinitive performs the function of a subject, while a noun together with a copula perform the function of a copulative-substantive predicate. The infinitive, denoting a potential action, receives an attitudinal or modal-attitudinal characteristic in a two-member sentence.

\section{References}

1. N.A. Gerasimenko, Russkaya grammatika: Strukturnaya organizatsiya yazyka $i$ protsessy yazykovogo funktsionirovaniya (M., LENAND, 2019)

2. A.A. Shakhmatov, Sintaksis russkogo yazyka (M., Editorial URSS, 2001)

3. Russkiy yazyk (M., Izdatel'skiy tsentr «Akademiya», 2001)

4. Russkaya grammatika. T. 2. Sintaksis (M., Nauka, 1980) 
5. V.N. Nemchenko, Grammaticheskaya terminologiya: slovar'- spravochnik (M., FLINTA: Nauka, 2011)

6. B.N. Golovin, Osnovy teorii sintaksisa sovremennogo russkogo yazyka (Nizhniy Novgorod, Izd-vo Nizhegorodskogo universiteta, 1994)

7. N.S. Valgina, Aktivnyye protsessy v sovremennom russkom yazyke (M., Logos, 2003)

8. P.A. Lekant, Tipy i formy skazuyemogo $v$ sovremennom russkom yazyke (M., IIU MGOU, 2017)

9. N.V. Yudina, Russkiy yazyk v XXI veke: krizis? evolyutsiya? progress? (M., Gnozis, 2010)

10. V.V. Babaytseva, Sintaksis russkogo yazyka: monografiya (M., FLINTA: Nauka, 2015)

11. Moskovskaya olimpiada shkol'nikov, https://mos.olimpiada.ru/tasks/arch_phylology

12. T.Ye. Shapovalova, Vestnik Moskovskogo gosudarstvennogo oblastnogo universiteta. Seriya: Russkaya filologiya 5, 34 (2010)

13. P.A. Lekant, Sintaksis prostogo predlozheniya v sovremennom russkom yazyke. 3-ye izd (M., Vysshaya shkola, 2004)

14. L.V. Popova, Svyazka v grammaticheskoy sisteme russkogo yazyka: monografiya (Arkhangel'sk, 2012)

15. A.M. Konyashkin, Infinitivno-podlezhashchnyye predlozheniya (struktura, semantika, klassifikatsiya) (Abakan, 2009)

16. N.D. Arutyunova, Yazyk i mir cheloveka (M., YAzyki russkoy kul'tury, 1999)

17. B.Y. Norman, Zhizn' slovoformy: uchebnoye posobiye (M., FLINTA: Nauka, 2016) 